\title{
The Effect of Supplementation of Cassava Leaves, Palm Oil Sludge and Yeast in Kumpai Grass-Based Rations on Ruminal Fermentation and Gas Methane Concentration In-Vitro
}

\author{
Riswandi $^{\mathrm{a},{ }^{*},}$, Arfan Abrar ${ }^{\mathrm{a}}$, Agus Wijaya ${ }^{\mathrm{b}}$, Basuni Hamzah ${ }^{\mathrm{b}}$ \\ ${ }^{a}$ Animal Science Department, Agriculture Faculty, Sriwijaya University, Ogan Ilir, 30662, Indonesia \\ ${ }^{b}$ Agricultural Product Technology Study Program, Faculty of Agriculture, Sriwijaya University, Ogan Ilir, 30662, Indonesia \\ Corresponding author: 'riswandi_dya@yahoo.com
}

\begin{abstract}
Swamp forage (kumpai grass), waste products from plantations, and agricultural industries are alternative feed for ruminants. To increase the value of its availability, yeast supplementation is needed. This study aimed to determine the effect of kumpai grass-based ration supplemented with cassava leaves, palm oil sludge, yeast on digestibility, rumen fermentation characteristics, and methane gas production. This study was determined using a Completely Randomized Design consisting of four treatments. The treatment is described as follows $70 \%$ grass $+30 \%$ Concentrate $(\mathrm{P0}, \mathrm{Con}), \mathbf{5 5} \%$ grass $+\mathbf{3 0} \%$ cassava leaves $+15 \%$ Concentrate + $0.05 \%$ yeast $(\mathrm{P} 1), \mathbf{5 5} \%$ grass $+30 \%$ palm oil sludge $+\mathbf{1 5 \%}$ concentrate $+\mathbf{0 . 0 5 \%}$ yeast $(\mathrm{P} 2)$, and $55 \%$ kumpai grass $+15 \%$ cassava leaves $+15 \%$ palm oil sludge $+15 \%$ concentrate $+0.05 \%$ yeast $(\mathrm{P} 3)$. Each treatment was incubated In-Vitro with a buffer solution (pH 6.9) and rumen of four replications (each repetition represented by three incubation bottles) for 48 hours at $39^{\circ} \mathrm{C}$. The data $\mathrm{obtained}$ were analyzed for variance; if there were a treatment effect, the Duncan test can be further tested. The results showed that supplementation affected the increase $(P<0.05)$ of dry matter digestibility, organic matter, crude protein, neutral detergent fiber, acid detergent fiber, total volatile fatty acids (total VFA), partial VFA, and total bacteria. Whereas, N-ammonia (N-NH3), the ratio of acetate-propionate and methane gas has decreased. It was concluded that supplementation of $15 \%$ cassava leaves, $15 \%$ palm oil sludge, and $\mathbf{0 . 0 5 \%}$ yeast in kumpai grass-based rations gave the best increase in the ration digestibility, total rumen bacterial count, rumen fermentation characteristics, and reduced methane concentration.
\end{abstract}

Keywords - Ruminal fermentation; methane gas; feed supplements; kumpai grass; volatile fatty acids.

\section{INTRODUCTION}

Swampland has the potential as a source of forage, kumpai grass (Hymenachne acutigluma), which can function as a fiber source. However, some problems occur, namely the high content of grass fiber fraction, to reduce feed digestibility and increase methane gas production [1]. Furthermore, high methane gas production has a negative impact in the form of a decrease in feed efficiency value; therefore, we need a solution to answer these problems. In this study, the solution needed to overcome this problem is to supplement probiotics, cassava leaves, and oil palm mud as concentrate feed replacement.

Nutritional supplementation with a balance of energy and protein and probiotics (yeast) aims to optimize rumen microbial growth by maximizing the use of fiber fractions in high fiber feed. Saccharomyces cerevisiae is a type of yeast probiotic that has been widely used as a dietary supplement in ruminants. Its effect in increasing cellulolytic bacterial populations reduces lactic acid accumulation [2]. Furthermore, Saccharomyces cerevisiae causes an increase in oxygen concentration in the rumen fluid and utilizes starch provided in the ration, which positively impacts livestock performance [3], [4]. The results prove that Saccharomyces cerevisiae supplementation increases fiber digestibility and increases crude protein degradation, fiber fraction, and microbial efficiency [5], [6].

The addition of cassava leaves in the ration; was reasonably caused by high branched amino acid content; The branchedchain amino acid (BCAA) content in cassava leaves consists of Valine $0.45 \%$, leucine $0.63 \%$, and isoleucine $0.46 \%$ [7]. Zhang et al. [8] reported that the addition of BCAAs in the ration could increase the growth of bacteria, which is reflected 
in the increased digestibility of dry matter, neutral detergent fiber (NDF), and acid detergent fiber (ADF).

Furthermore, to increase the ratio's nutrient content and reduce methane gas production, the addition of oil palm mud to the ration is essential. Palm sludge is a waste of the palm oil processing industry and is a source of unsaturated fatty acids in $39.58 \%$ oleic acid and $9.92 \%$ linoleic acid [9]. The unsaturated fatty acids can affect the decline in methane gas production to increase propionic acid production. The increase in propionic acid is manipulation for the formation of ruminant livestock meat [10]. Hence, it is necessary to research the effect of supplementation of cassava leaves, palm oil sludge, and yeast on digestive quality, rumen fermentation characteristics, and methane gas concentration In-Vitro.

\section{MATERIAL AND Method}

\section{A. Experimental Design and Sample Preparation}

This research was conducted using a completely randomized design with four treatments; described as follows $70 \%$ kumpai grass $+30 \%$ concentrate $+0 \%$ (control, $\mathrm{P} 0$ ), $55 \%$ kumpai grass $+30 \%$ cassava leaves $+15 \%$ concentrate $+0.05 \%$ yeast (P1), 55\% kumpai grass $+30 \%$ Palm oil Sludge $+15 \%$ concentrate $+0.05 \%$ yeast $(\mathrm{P} 2)$, and $55 \%$ kumpai grass $+15 \%$ cassava leaves $+15 \%$ Palm oil Sludge $+15 \%$ concentrate + . $0.05 \%$ yeast $(\mathrm{P} 3)$.

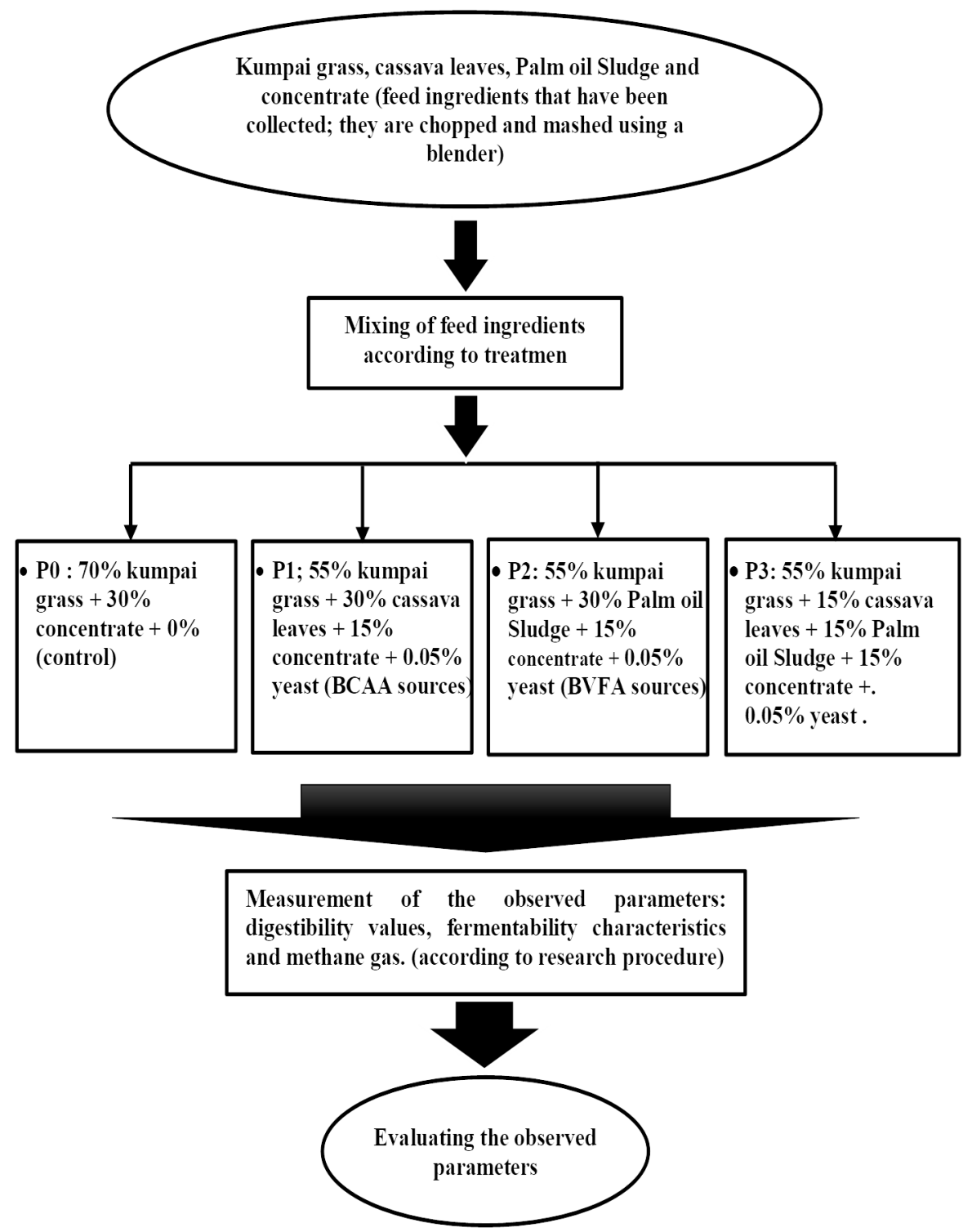

Fig. 1 Flowchart of the process of making treatment samples

The sample preparation in this study was carried out through 2 stages: first, the collection of feed ingredients composing the treatment ration consisting of kumpai grass, cassava leaves, palm oil sludge, yeast, and concentrate. The kumpai grass obtained came from swampland in Rambutan village, Indralaya district. Cassava leaves are obtained from cassava crop farmers in Tanjung Pering village, Indralaya district. Previously, the process of reducing water content has been carried out with the hay method. Furthermore, Palm mud was obtained from the waste of PT Ben's palm oil processing 
factory in Rambutan Indralaya village. In contrast, yeast was obtained from the Bogor Ciawi Animal Research Institute.

Second, feed ingredients that have been collected; they are chopped and mashed using a blender; Thus, the continued process of mixing a small amount of material in advance, such as yeast and concentrate. It is mixed with feed ingredients with larger particle sizes such as cassava leaves, palm oil, and kumpai grass after mixing evenly. Mixing is done until homogeneous. As for the flowchart of the process of making treatment samples can be seen in Figure 1.

Furthermore, the ration nutrition quality measurement was carried out based on proximate analysis, fiber fraction, total rumen microbes, digestibility, and rumen fermentation ability In-Vitro. The study of the constituent feed ingredients' chemical composition and the ratio of treatment rations can be seen in Table I and Table II.

TABLE I

The Chemical Composition Of Kumpai Grass (KG), CASSAVA LeAVES (Cl), PALM OIL Sludge (Pos), AND CONCENTRATE (CON) (\% DM)

\begin{tabular}{lcccc}
\hline Nutrient & KG & CL & POS & CON \\
\hline Dry matter & 91.86 & 88.75 & 90.76 & 80.59 \\
Organic matter & 88.52 & 78.96 & 83.23 & 63.21 \\
Crude protein & 8.43 & 20.34 & 18.85 & 15.62 \\
Crude fiber & 32.85 & 23.64 & 13.54 & 11.24 \\
Ether extract & 4.64 & 7.92 & 18.93 & 6.99 \\
Neutral detergent fiber & 58.43 & 30.58 & 46.37 & 37.71 \\
Acid detergent fiber & 46.35 & 22,34 & 35.32 & 21.66 \\
Hemicellulose & 12.08 & 8.24 & 11.14 & 16.05 \\
Cellulose & 26,64 & 16.72 & 27.21 & 15.86 \\
Lignin & 13,51 & 4.62 & 7.25 & 3.52 \\
Oleate & 0.05 & 0.13 & 42.18 & 1.42 \\
Linoleic & 0.22 & 0.38 & 11.24 & 1.58 \\
Valine & 0.03 & 0.63 & 0.39 & 0.43 \\
Leucine & 0.07 & 0.75 & 0.48 & 0.37 \\
Isoleucine & 0.12 & 0.67 & 0.43 & 0.28 \\
\hline
\end{tabular}

TABLE II

INGREDIENTS AND CHEMICAL COMPOSITIONS OF THE EXPERIMENTAL DIETS (\% DM)

\begin{tabular}{lcccc}
\hline \multirow{2}{*}{ Ingredients } & \multicolumn{4}{c}{ Diet } \\
\cline { 2 - 5 } & P0 & P1 & P2 & P3 \\
\hline Kumpai grass (\%) & 70 & 55 & 55 & 55 \\
Cassava leaves (\%) & 0 & 30 & & 15 \\
Palm oil sludge (\%) & 0 & & 30 & 15 \\
Concentrate (\%) & 30 & 15 & 15 & 15 \\
Yeast (\%) & 0 & 0.05 & 0.05 & 0.05 \\
TOTAL & 100 & 100 & 100 & 100 \\
Dry matter & 88.48 & 88.81 & 89.76 & 89.54 \\
Organic matter & 80.87 & 83.19 & 84.09 & 82.47 \\
Crude protein (\%) & 11.29 & 13.63 & 13.18 & 13.41 \\
Crude fiber (\%) & 28.37 & 25.85 & 23.81 & 25.33 \\
Ether extract (\%) & 5.79 & 6.15 & 9.62 & 7.93 \\
Neutral detergent fiber (\%) & 52.21 & 46.97 & 51.33 & 49.35 \\
Acid detergent fiber (\%) & 39.94 & 35.44 & 38.84 & 36.65 \\
Hemicellulose (\%) & 13.27 & 11.71 & 12.39 & 12.05 \\
Cellulose (\%) & 23.41 & 22.05 & 25.19 & 23.62 \\
Lignin (\%) $\%$ (\%) & 10.51 & 9.35 & 10.13 & 9.13 \\
Oleate (\%) & 0.46 & 0.28 & 12.89 & 6.59 \\
Linoleic (\%) & 0.63 & 0.47 & 3.73 & 2.10 \\
Valine (\%) & 0.15 & 0.27 & 0.20 & 0.23 \\
Leucine (\%) & 0.16 & 0.32 & 0.24 & 0.28 \\
Isoleucine (\%) & 0.08 & 0.27 & 0.24 & 0.27 \\
\hline
\end{tabular}

\section{B. In-Vitro Incubation, Rumen Fermentation Characteristics, and Gas Production.}

According to the Tilley and Terry method in many previous studies, objectivity observations were based on In-Vitro process [11]. Rumen fluid is taken from slaughterhouses and filtered with four layers of cheesecloth. One part of rumen fluid $(10 \mathrm{~mL})$ is mixed with four pieces of media $(40 \mathrm{~mL})$ consisting of buffer solution, macro and micro mineral solution, resazurin, and reduction solution [12]. One gram of sample is put into a $100 \mathrm{~mL}$ incubation tube and then added with $50 \mathrm{ml}$ of the mixed solution before the tube is closed; $\mathrm{CO} 2$ gas is drained for 30 seconds and is incubated for 24 hours. After the incubation time is finished, add two drops of $\mathrm{HgCl}$.

The sample and incubation media were centrifuged in tubes at $4000 \mathrm{rpm}$ for 10 minutes to separate the supernatant and the residue. The supernatant was taken to further analyze NAmmonia (N-NH3) concentration, total volatile fatty acid (VFAT), partial VFA, total gas production, methane gas, and calculation of the total number of bacteria. The concentration of N-NH3 in the modified Conway procedure [13]; The VFA content was analyzed using Gas-Liquid Chromatography (GLC Bruker Scion 436-GC, Bruker Daltonik GmbH, Bremen, Germany) using columns (BR-Wax fame, mmlD $0.32,0.25 \mathrm{~lm} \mathrm{df}$ ) and FID detectors. Supernatant preparations obtained from In-Vitro incubation were added with $3 \mathrm{mg}$ of sulfosalicylic acid dehydrate, centrifuged for 10 minutes at 12 $000 \mathrm{rpm}$ at $7^{\circ} \mathrm{C}$, and then injected into the GLC column.

VFA quantification in acetate, propionate, and butyrate was obtained by comparing them with external standards. It was determined as $\mu \mathrm{mol} / \mathrm{ml}$ or $\mathrm{mM}$. The total VFA content was obtained by the sum of the respective VFA constituents [14]. Gas production and methane concentration were carried out after incubation for 24 hours by taking fermented gas samples of $3 \mathrm{~mL}$ using a syringe glass. Thus, gas samples stored in venoject tubes analyzed methane gas concentration using Gas-Liquid Chromatography (GLC, HEWLETT PACKARD, 3700, USA) [15]. Total bacteria, according to the Ogimoto procedure [16]. Analysis of food content using incubated residue, then added with $50 \mathrm{~mL}$ pepsin- $\mathrm{HCl} 0.20 \%$ and incubated for 48 hours. The solution was then filtered using Whatman filter paper No. 41 , then dried for 48 hours at $60{ }^{\circ} \mathrm{C}$ to analyze food substances' digestibility value.

\section{Analysis of Chemical Composition and Digestibility.}

This study also analyzed the chemical composition according to AOAC procedures [14], which includes dry matter (DM), organic matter (OM), and crude protein (CP) as the analysis of fiber fraction content includes NDF and ADF, according to the van Soest procedure [17]. Furthermore, the observations on the quality of digestion include digestion of dry matter (DMD), digestibility of organic matter (OMD), and digestion of fiber fractions, including NDF and ADF. They were measured based on the amount of nutrient content and the fraction of fiber lost. The difference between the sample before incubation In-Vitro with the residual sample from InVitro incubation.

\section{Statistical Analysis.}

The data obtained were statistically analyzed according to the SAS 9.4 User Guide (SAS Inst, Inc, Cary, NC). If there is 
a treatment effect will be further tested by the Duncan test [18].

\section{RESULTS AND DISCUSSION}

In-Vitro fermentation, experimental research was conducted to measure feed ingredients' digestibility and microbial activity during fermentation in the rumen. The variables observed included $\mathrm{DMD}$, OMD, crude protein digestibility, and digestion of fiber fractions, including Neutral Detergents Fiber (NDF) and Acid Detergents Fiber (ADF). The fermentation characteristics include $\mathrm{pH}$, Ammonia (NH3), and volatile Fatty Acid (VFA). Furthermore, observations of the byproducts of fermentation production were also carried out to determine the quality of fermentation results, including total gas production, methane gas concentrations, and total bacteria.

The results of observations of the fermentation characteristics showed exciting results, as presented in Table III. At the $\mathrm{pH}$ value, there were no significant differences between treatments $(\mathrm{P}>0.05)$. However, there was a decrease in ammonia concentration (N-NH3) in $\mathrm{P} 1, \mathrm{P} 2$, and $\mathrm{P} 3$ treatments compared to $\mathrm{P} 0 \quad(\mathrm{P}<0.05)$. The lowest concentration was found in the $\mathrm{P} 3$ treatment, followed by $\mathrm{P} 1$ and $\mathrm{P} 2$ (P1 vs. P2, P>0.05). Furthermore, the reverse results are shown in the total value of VFA; where the increase occurred in the P3 treatment with the highest VFA value compared to other treatments; which were then followed sequentially in the treatments $\mathrm{P} 1, \mathrm{P} 2$, and $\mathrm{P} 0$ (P1 vs. P2 vs. P0, $\mathrm{P}<0.05)$. The results can be seen in Table IV.

TABLE III

EFFECT OF TREATMENTS ON FERMENTATION CHARACTERISTIC (PH, N-NH ${ }_{3}$, AND VFA TOTAL)

\begin{tabular}{llll}
\hline \multicolumn{1}{c}{ Treatment } & $\mathbf{p H}$ & \multicolumn{1}{c}{$\mathbf{N}^{-N_{H}} \mathbf{3}(\mathbf{m M})$} & \multicolumn{1}{c}{ VFA Total $(\mathbf{m M})$} \\
\hline P0 & 6.69 & $8.67^{\mathrm{c}}$ & $63.76^{\mathrm{a}}$ \\
P1 & 6.61 & $7.30^{\mathrm{b}}$ & $115.25^{\mathrm{c}}$ \\
P2 & 6.72 & $6.44^{\mathrm{b}}$ & $86.16^{\mathrm{b}}$ \\
P3 & 6.75 & $5.31^{\mathrm{a}}$ & $127.70^{\mathrm{c}}$ \\
SEM & 0.02 & 0.45 & 7.00 \\
$P$-Value & 0.153 & 0.038 & $<0.0001$ \\
\hline a,b,c,d significantly different in a column $(\mathrm{P}<0.05)$. &
\end{tabular}

TABLE IV

EFFECT OF TREATMENTS ON VFA PRODUCTION IN RUMEN

\begin{tabular}{lllll}
\hline Treatment & $\begin{array}{c}\text { Acetate } \\
(\mathbf{m M})\end{array}$ & $\begin{array}{c}\text { Propionate } \\
(\mathbf{m M})\end{array}$ & $\begin{array}{c}\text { Butyrate } \\
(\mathbf{m M})\end{array}$ & $\begin{array}{c}\text { Ratio } \\
\mathbf{A} / \mathbf{P}\end{array}$ \\
\hline $\mathrm{P} 0$ & $37.96^{\mathrm{a}}$ & $16.15^{\mathrm{a}}$ & $9.64^{\mathrm{a}}$ & $2.36^{\mathrm{c}}$ \\
$\mathrm{P} 1$ & $65.11^{\mathrm{b}}$ & $32.95^{\mathrm{b}}$ & $17.19^{\mathrm{c}}$ & $1.97^{\mathrm{b}}$ \\
$\mathrm{P} 2$ & $40.39^{\mathrm{a}}$ & $30.34^{\mathrm{b}}$ & $15.43^{\mathrm{b}}$ & $1.35^{\mathrm{a}}$ \\
$\mathrm{P} 3$ & $73.43^{\mathrm{b}}$ & $39.93^{\mathrm{c}}$ & $14.34^{\mathrm{b}}$ & $1.84^{\mathrm{b}}$ \\
SEM & 4.53 & 2.39 & 0.80 & 0.12 \\
$P-$ Value & $<0.0001$ & $<0.0001$ & $<0.0001$ & $<0.0001$ \\
\hline a,b,c,d significantly different in a column $(\mathrm{P}<0.05)$. &
\end{tabular}

Based on the analysis results in Table V, it was shown that treatments P1 and P3 had the highest DMD and OMD values compared to other treatments $(\mathrm{P}<0.05)$, which was then followed by $\mathrm{P} 2$ treatment compared to $\mathrm{P} 0$ treatment (P2 vs. $\mathrm{P} 0, \mathrm{P}<0.05)$. Furthermore, the same pattern was shown in the NDF digestibility value $(\mathrm{P}<0.05)$. Meanwhile, the digestibility value of crude protein and ADF showed contrast results. The increased digestibility was established in the P1 and $\mathrm{P} 3$ treatments compared to the $\mathrm{P} 0$ treatment $(\mathrm{P}<0.05)$;
However, an increase in P1 was not followed by a significant difference compared to the $\mathrm{P} 2$ treatment $(\mathrm{P}>0.05)$. The digestibility values of crude protein, NDF, and ADF can be seen in Table VI.

TABLE V

EFFECT OF TREATMENTS ON DIGESTIBILITY OF DRY MATTER (DM) AND ORGANIC MATTER (OM)

\begin{tabular}{lcc}
\hline \multirow{2}{*}{ Treatment } & \multicolumn{2}{c}{ Digestibility (\%) } \\
\cline { 2 - 3 } & DM & OM \\
\hline P0 & $50.65^{\mathrm{a}}$ & $52.15^{\mathrm{a}}$ \\
P1 & $58.37^{\mathrm{b}}$ & $60.65^{\mathrm{c}}$ \\
P2 & $53.41^{\mathrm{a}}$ & $56.43^{\mathrm{b}}$ \\
P3 & $59.76^{\mathrm{b}}$ & $61.58^{\mathrm{c}}$ \\
SEM & 1.08 & 1.00 \\
P-Value & $<0.0001$ & $<0.0001$ \\
\hline a,b,c,d significantly different in a column $(\mathrm{P}<0.05)$.
\end{tabular}

TABLE VI

EFFECT OF TREATMENTS ON DigestiBILITY OF CRUDE ProteIn, NEUTRAL DETERGENT FIBER (NDF), AND ACID DETERGENT FIBER (ADF).

\begin{tabular}{|c|c|c|c|}
\hline \multirow{2}{*}{ Treatment } & \multicolumn{3}{|c|}{ Digestibility (\%) } \\
\hline & $\mathbf{C P}$ & NDF & ADF \\
\hline P0 & $60.65^{\mathrm{a}}$ & $50.69^{a}$ & $49.59^{\mathrm{a}}$ \\
\hline P1 & $64.25^{b}$ & $54.83^{\mathrm{bc}}$ & $51.57^{\mathrm{b}}$ \\
\hline $\mathrm{P} 2$ & $63.36^{\mathrm{b}}$ & $54.04^{b}$ & $50.96^{\mathrm{b}}$ \\
\hline P3 & $64.37^{\mathrm{b}}$ & $55.22^{\mathrm{c}}$ & $52.06^{\mathrm{b}}$ \\
\hline SEM & 0.49 & 0.48 & 0.33 \\
\hline P-Value & 0.007 & $<0.0001$ & 0.030 \\
\hline
\end{tabular}

TABLE VII

EFFECT OF TREATMENTS ON GAS Production (GP), MEthane CONCENTRATION, AND TOTAL BACTERIA.

\begin{tabular}{llll}
\hline Treatment & \multicolumn{1}{c}{$\begin{array}{c}\text { Gas } \\
\text { production } \\
(\mathbf{m l})\end{array}$} & $\begin{array}{c}\text { Methane } \\
\text { Concentration } \\
(\mathbf{p p m})\end{array}$ & $\begin{array}{c}\text { Total } \\
\text { microbial } \\
\left(\mathbf{1 0}^{\mathbf{1 0}} \mathbf{c f u}\right)\end{array}$ \\
\hline P0 & $28.00^{\mathrm{a}}$ & $6175.79^{\mathrm{b}}$ & $3.77^{\mathrm{a}}$ \\
P1 & $34.75^{\mathrm{b}}$ & $537.97^{\mathrm{a}}$ & $5.37^{\mathrm{b}}$ \\
P2 & $36.00^{\mathrm{b}}$ & $415.11^{\mathrm{a}}$ & $5.48^{\mathrm{b}}$ \\
P3 & $36.15^{\mathrm{b}}$ & $736.45^{\mathrm{a}}$ & $6.47^{\mathrm{c}}$ \\
SEM & 1.01 & 6.62 & 0.26 \\
P-Value & 0.011 & $<0.0001$ & $<0.0001$ \\
\hline a,b,c,d significantly different in a column $(\mathrm{P}<0.05)$. &
\end{tabular}

Based on the analysis results in table VII, there was a significant increase in gas production in the treatments $\mathrm{P} 1, \mathrm{P} 2$, and $\mathrm{P} 3$ compared to the $\mathrm{P} 0$ treatment $(\mathrm{P}<0.05)$. Conversely, methane gas concentration showed a significant decrease in $\mathrm{P} 1, \mathrm{P} 2$, and $\mathrm{P} 3$ treatments compared to the P0 treatment ( $\mathrm{P}$ $<0.05)$. Furthermore, the total microbial observation showed a significant increase in the microbial population in P3 treatment compared to other treatments $(\mathrm{P}<0.05)$.

A. Effect of Cassava Leaves, Palm Oil Sludge, and Yeast Supplementation on Rations based Kumpai Grass on the Characteristics of Fermentation ( $\mathrm{HH}, \mathrm{N}-\mathrm{NH} 3$, Total VFA, and Partial VFA)

This study's $\mathrm{pH}$ value ranged between $6.61-6.75$ so that it did not interfere with microbial growth in the rumen. The reasonable condition of the rumen $\mathrm{pH}$ is 6.0-6.9 [19]. This ideal $\mathrm{pH}$ value is achieved because the yeast activity reduces lactic acid accumulation in the rumen [3],[4]. Khan et al. [2] stated that yeast Saccharomyces cerevisiae's supplemented to 
a high-energy ration could stabilize rumen $\mathrm{pH}$ and prevent acidosis. Besides, the balance of fermented products, VFA and $\mathrm{N}-\mathrm{NH} 3$, can also stabilize the rumen $\mathrm{pH} ; \mathrm{N}-\mathrm{NH} 3$ is produced from microbes' protein degradation. The N-NH3 produced is then used as a source of nitrogen for microbial protein synthesis [20].

Low levels of ammonia in dietary supplements (P1, P2, and P3) indicate the high utilization of N-NH3 as a source of nitrogen for rumen microbes. The increased activity sees this of rumen microbes in digesting nutrients; Furthermore, Suryani et al. [21] stated that microbes used the rumen NNH3 compound for its growth to increase feed digestibility. Furthermore, the indicated low N-NH3 concentration was suspected because it was used for microbial growth in the rumen; high levels saw VFA produced in P1, P2, P3 compared to controls.

This study also showed an increase in VFA; As for the increase is suspected of having a relationship with increased nutritional digestibility. As a result, the higher the ratio's digestibility value, the level of TVFA also increases. TVFA levels in this study are still in the normal range to guarantee rumen microbial activity and growth, ranging from 63.76 $127.70 \mathrm{mM}$. This TVFA value is lower than the research results in Riswandi et al. [22], which reported that supplementation of different legumes consisted of Kemon (Neptunia olerancia), lamtoro leaf (Leucaena leucocephala), and acacia. Each $5 \%$ in the grass-based ration produced TVFA ranging from 70.02 - $158.84 \mathrm{mM}$. According to McDonald [20], the optimal VFA content for rumen microbial growth is $80-160 \mathrm{mM}$. Bannink et al [23] stated that the composition of VFA formed in the rumen is influenced by the fermented substrate, microbial population, and rumen ecology.

The results showed that dietary supplements showed an increase in $\mathrm{C} 2, \mathrm{C} 3$, and $\mathrm{C} 4$ compared to control treatments. An increase also followed an increase in $\mathrm{C} 2$ and $\mathrm{C} 4$ in $\mathrm{C} 3$. Partial VFA can predict the value of ration efficiency in the form of a comparison between $\mathrm{C} 2$ and $\mathrm{C} 3$ (C2 / C3). Our results are in Zhang et al. [8], which found $\mathrm{C} 2, \mathrm{C} 3$, and $\mathrm{C} 4$ production increased with the BCAA diet. The results showed that dietary supplements showed a decrease in the $\mathrm{C} 2$ / C3 ratio in the rumen.

This decrease also has to do with yeast activity, as reported by [24]. The smaller the $\mathrm{C} 2$ / C3 ratio value, the higher the ration efficiency [25]. This study's results were lower than [26], showed that supplementation of banana humps and molasses in ammoniated rice straw-based feed produced a $\mathrm{C} 2$ / C3 ratio of 3.32-3.45. This study's low C2 / C3 ratio is thought to be due to the high efficiency of livestock use. The low ratio or $\mathrm{C} 2$ / $\mathrm{C} 3$ ratio is due to the high fermentable organic matter in dietary supplementation; this allows the propionic acid formation to be higher than acetic acid. Propionic acid is the primary precursor for blood glucose formation and is glucogenic [27]. The $\mathrm{C} 2$ / C3 ratio value is closely related to methane gas production; the lower the $\mathrm{C} 2$ / $\mathrm{C} 3$ ratio value, the lower the methane production.

\section{B. The Effect of Cassava Leaves, Palm Oil Sludge, and Yeast Supplementation on Nutrient Digestibility.}

The effect of dietary supplements increases $(\mathrm{P}<0.05)$ the value of nutrient digestibility; the activity of yeast causes this as a rumen controller [3], [4]; thus, being able to support the growth of rumen microbes to degrade nutrients [5], [6]. The lower fiber fraction content and high crude protein from dietary supplements will also increase degradation [20]. The effect of cassava leaf supplement (P1) on rumen degradation equals P3, which consists of a combination of cassava leaves and oil palm sludge; this is due to the high BCAA content in cassava leaves (Table 1), which functions as a carbon frame for the growth of fiber digesting bacteria [28]. Zhang et al. [8] stated that the addition of BCAAs increased the digestibility of DM and NDF. The carbon frame source was obtained by decarboxylation and deaminase of branched-chain amino acids. Which were Valine, leucine, and isoleucine transformed into isobutyric, 2-methyl butyric, and isovaleric acids. The process of deamination and decarboxylation of BCAAs into BCVFA can be described as follows (29)

$$
\begin{aligned}
& \mathrm{R}-\mathrm{CH}\left(\mathrm{NH}_{2}\right) \mathrm{COOH}+\mathrm{H}_{2} \mathrm{O} \rightarrow \mathrm{RCOCOOH}+\mathrm{NH}_{3}+2 \mathrm{H}^{+} \\
& \mathrm{RCOCOOH}+\mathrm{H}_{2} \mathrm{O} \rightarrow \mathrm{RCOOH}+\mathrm{CO}_{2}+2 \mathrm{H}^{+} \\
& \text {Where: } \\
& \begin{aligned}
\mathrm{R} & =\left(\mathrm{CH}_{3}\right)_{2} \mathrm{CH}-\text { (valine) } \\
\quad & =\left(\mathrm{CH}_{3}\right)_{2} \mathrm{CHCH}-\text { (leucine) } \\
\quad & =\mathrm{CH}_{3} \mathrm{CH}_{2} \mathrm{CH}\left(\mathrm{CH}_{3}\right) \text { - (isoleucine) }
\end{aligned}
\end{aligned}
$$

Oil palm sludge supplement (P2) has a degradation effect on dry matter, organic matter, and rumen. NDF lower than P1 and P3. this is due to the high content of unsaturated fatty acids from oil palm sludge (Table 1). It affects the activity of cellulolytic bacteria in digesting fiber [30]. The availability of BCAAs and unsaturated fatty acids together in P3 (Table 2) is an optimal $\mathrm{N}$ and energy source for rumen microbial growth to degrade nutrients.

\section{The Effect of Cassava Leaves, Palm oil Sludge, and Yeast Supplementation on Rations based on Kumpai Grass on Gas Production, Methane Gas Concentration, and Total Microbes.}

Gas production is a picture of fermented organic matter in the rumen [31] to evaluate the nutritional value of feed [32]. The total gas production due following increased rumen's microbial activity and it was related to increased digestibility and rumen fermentability [33]. Mitsumori and Sun [34] stated that the total level of gas production In-Vitro fermentation depends on the composition of nutrient content such as (fiber, carbohydrates, protein), the presence of inhibitors for gas production, the quality of the ruminant diet, and the fermentation activity of microorganisms in rumen fluid.

Dietary supplements produce methane gas concentrations lower than control; low methane gas concentrations illustrate an increase in the value of hexose conversion efficiency, which means the rumen fermentation system, which leads to the synthesis of propionate acid [35]. The reduction in methane gas concentration correlates with the amount of $\mathrm{C} 2$ / $\mathrm{C} 3$ ratio in $\mathrm{P} 1, \mathrm{P} 2$, and $\mathrm{P} 3$ treatments and has lower than controls. These relationships have an attachment to the $\mathrm{C} 2$ production process, which produces carbon dioxide [20]; thus, the lower $\mathrm{C} 2$ than $\mathrm{C} 3$, methane gas production will decrease because the supply of hydrogen methanogenesis is limited [35]. According to Martin et al. [36], an increase in fiber content in the ration can occur due to the high $\mathrm{C} 2$ / $\mathrm{C} 3$ ratio, resulting in higher $\mathrm{CH} 4$ production. Furthermore, unsaturated 
fatty acids and crude protein content can also reduce methane gas following the study's results in [37], [38]. Also, yeast supplementation was thought caused by stimulating acetogenins to compete using hydrogen with methanogens to reduce methane emissions [35].

The effect of dietary supplementation on treatment (P3) results in higher total rumen microbes than other treatments. This increase occurred positively related to digestibility value and rumen fermentability characteristics. VFA and NH3 compounds obtained from fermented carbohydrates and proteins play an essential role as energy sources and $\mathrm{N}$ for rumen microbes [20]. This increase was also due to yeast activity, as reported by [3]. Finally, supplementation of cassava leaves, palm mud, and treated yeast has shown promising initial results for digestive coefficients, rumen fermentability characteristics, and methane gas. This experiment's results can be applied in in vivo experiments on goats and cattle, which are expected to improve feed efficiency and livestock performance.

\section{CONCLUSION}

This study concludes that supplementation of $15 \%$ cassava leaves, $15 \%$ palm oil sludge, and $0.05 \%$ yeast in kumpai grass-based rations gave the best increase in the ration digestibility, total rumen bacterial count, rumen fermentation characteristics, and reduced methane concentration.

\section{ACKNOWLEDGMENT}

The authors are grateful to Sriwijaya University for providing research funding through a competitive flagship scheme.

\section{REFERENCES}

[1] A. I. M. Ali, S. Sandi, Muhakka, Riswandi, and D. Budianta, "The Grazing of Pampangan Buffaloes at Non Tidal Swamp in South Sumatra of Indonesia," APCBEE Procedia, vol. 8, no. CAAS 2013, pp. 87-92, 2014, doi: 10.1016/j.apcbee.2014.03.006

[2] R. Ullah Khan et al., "Direct-fed microbial: Beneficial applications, modes of action and prospects as a safe tool for enhancing ruminant production and safeguarding health," International Journal of Pharmacology, vol. 12, no. 3, pp. 220-231, 2016, doi: 10.3923/ijp.2016.220.231

[3] D. S. Kumar, C. S. Prasad, and R. M. V. Prasad, "Effect of Yeast Culture (Saccharomyces Cerevisiae) on Ruminal Microbial Population in Buffalo Bulls," in Buffalo Bulletin, vol. 32, no. 2, S. Sophon, Ed. Bangkok, Thailand: International Buffalo Information Centre, Office of University Library, Kasetsart University, 2013, pp. $116-119$.

[4] E. Pinloche, N. McEwan, J. P. Marden, C. Bayourthe, E. Auclair, and C. J. Newbold, "The Effects of a Probiotic Yeast on the Bacterial Diversity and Population Structure in the Rumen of Cattle," PLoS ONE, vol. 8, no. 7, 2013, doi: 10.1371/journal.pone.0067824.

[5] A. I. M. Ali, S. Sandi, . R., A. Imsya, A. Prabowo, and N. Rofiq, "Evaluation of Yeast Supplementation with Urea-Molasses in Rice Straw-Based Diets on In-Vitro Ruminal Fermentation," Pakistan Journal of Nutrition, vol. 14, no. 12, pp. 988-993, Dec. 2015, doi: 10.3923/pjn.2015.988.993.

[6] S. X. Tang et al., "Effects of yeast culture and fibrolytic enzyme supplementation on In-Vitro fermentation characteristics of lowquality cereal straws1," Journal of Animal Science, vol. 86, no. 5, pp. 1164-1172, May 2008, doi: 10.2527/jas.2007-0438.

[7] N. Nurhaita, L. Warly, Z. Mardiati, R. S.-J. P. U. J. Seri, and undefined 2010, "Sintesis protein mikroba pada domba yang mendapat ransum daun sawit amoniasi yang disuplementasi mineral S, P dan daun ubi kayu," Jurnal Penelitian Universitas Jambi Seri Sains, vol. 12, pp. 107-114, 2010
[8] H. L. Zhang, Y. Chen, X. L. Xu, and Y. X. Yang, "Effects of Branched-chain Amino Acids on In-Vitro Ruminal Fermentation of Wheat Straw," Asian-Australasian Journal of Animal Sciences, vol. 26, no. 4, pp. 523-528, 2013, doi: 10.5713/ajas.2012.12539.

[9] A. Hayyan et al., "Production of Biodiesel from Sludge Palm Oil by Esterification Process," Energy and power engineering, vol. 4, no. 1, pp. 11-17, 2010, doi: 10.17265/1934-8975/2010.01.002.

[10] A. MacHmüller, D. A. Ossowski, and M. Kreuzer, "Comparative evaluation of the effects of coconut oil, oilseeds and crystalline fat on methane release, digestion and energy balance in lambs," Animal Feed Science and Technology, vol. 85, no. 1-2, pp. 41-60, 2000, doi: 10.1016/S0377-8401(00)00126-7.

[11] J. M. A. Tilley and R. A. Terry, "A Two-Stage Technique for the InVitro Digestion of Forage Crops," Grass and Forage Sci Grass and Forage Science, vol. 18, no. 2, pp. 104-111, 1963.

[12] H. K. Goering and P. J. Van, "Forage fiber analyses," U.S. Department of Agriculture, no. 379, pp. 387-598, 1975.

[13] E. J. Conway and E. O'Malley, "Microdiffusion methods. Ammonia and urea using buffered absorbents (revised methods for ranges greater

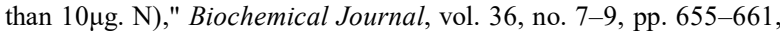
Sep. 1942, doi: 10.1042/bj0360655.

[14] AOAC, Official Methods of Analysis of AOAC INTERNATIONAL, 18th ed., no. February. Gaithersburg, MD: AOAC International, 2005.

[15] Menke and $\mathrm{KH}$, "Estimation of the energetic feed value obtained from chemical analysis and In-Vitro gas production using rumen fluid," Animal Research and Development, vol. 28, pp. 7-55, 1988.

[16] K. Ogimoto and S. Imai, Atlas of rumen microbiology. Tokyo : Japan scientific societies press, 1981.

[17] P. J. Van Soest, Nutritional ecology of the ruminant: ruminant metabolism, nutritional strategies, the cellulolytic fermentation and the chemistry of forages and plant fibers. Ithaca [N.Y.]: Comstock Pub. Associates, 1988.

[18] R. G. D. Steel and J. H. Torrie, Principles and procedures of statistics. New York: McGraw-Hill, 1980.

[19] D. N. Kamra, "Rumen microbial ecosystem," Current Science, vol. 89 no. 1, pp. 124-135, May 2005.

[20] P. McDonald, Animal nutrition. Harlow, England; New York: Prentice Hall/Pearson, 2011.

[21] N. N. Suryani, I. G. Mahardika, S. Putra, and N. Sujaya, "Enhancement Provision Of Gliricidia Sepium In Diet Increase Nitrogen Balance And Population Of Rumen Proteolitik Microorganism Of Bali Cattle)," Jurnal Veteriner, vol. 16, no. 1, pp. 117-123, 2015.

[22] R. Riswandi, L. Priyanto, A. Imsya, and M. Nopiyanti, "In-Vitro Digestibility of Fermented Hymenacne Acutigluma-Based Rations Supplemented with Different Legumes," Jurnal Veteriner, vol. 18, no. 2, p. 303, 2017, doi: 10.19087/jveteriner.2017.18.2.303.

[23] A. Bannink et al., "Modelling the implications of feeding strategy on rumen fermentation and functioning of the rumen wall," Animal Feed Science and Technology, vol. 143, no. 1-4, pp. 3-26, 2008, doi: 10.1016/j.anifeedsci.2007.05.002.

[24] L. Riyanti, Suryahadi, and D. Evvyernie, "In-Vitro fermentation characteristics and rumen microbial population of diet supplemented with Saccharomyces cerevisiae and rumen microbe probiotics," Media Peternakan, vol. 39, no. 1, pp. 40-45, 2016, doi: 10.5398/medpet.2016.39.1.40.

[25] E. R. Ørskov and M. Ryle, Energy nutrition in ruminants. Barking: Elsevier Science Publishers Ltd, 1990

[26] R. I. Rahayu, A. Subrata, and J. Achmadi, "In-Vitro Ruminal Fermentability on Ammoniated Rice Straw Based Diet With Supplementation of Banana Tree Root Ball and Molasess," Indonesian Journal of Animal Science, vol. 20, no. 3, p. 166, Oct. 2018, doi: 10.25077/jpi.20.3.166-174.2018.

[27] B. Vlaeminck et al., "Milk odd- and branched-chain fatty acids in relation to the rumen fermentation pattern," Journal of Dairy Science, vol. 89 , no. 10 , pp. 3954-3964, 2006, doi: 10.3168/jds.S00220302(06)72437-7.

[28] L. O. Tedeschi, D. G. Fox, M. A. Fonseca, and L. F. L. Cavalcanti, "Models of protein and amino acid requirements for cattle," Revista Brasileira de Zootecnia, vol. 44, no. 3, pp. 109-132, Mar. 2015, doi: 10.1590/S1806-92902015000300005.

[29] V. Fievez, B. Vlaeminck, T. Jenkins, F. Enjalbert, and M. Doreau, "Assessing rumen biohydrogenation and its manipulation in vivo, InVitro and in situ," European Journal of Lipid Science and Technology, vol. 109, no. 8, pp. 740-756, 2007, doi: 10.1002/ejlt.200700033.

[30] W. F. Pellikaan, W. H. Hendriks, G. Uwimana, L. J. G. M. Bongers, P. M. Becker, and J. W. Cone, "A novel method to determine simultaneously methane production during In-Vitro gas production 
using fully automated equipment," Animal Feed Science and Technology, vol. 168, no. 3-4, pp. 196-205, 2011, doi: 10.1016/j.anifeedsci.2011.04.096.

[31] M. M. Y. Elghandour, A. E. Kholif, A. Z. M. Salem, O. A. Olafadehan, and A. M. Kholif, "Sustainable anaerobic rumen methane and carbon dioxide productions from prickly pear cactus flour by organic acid salts addition," Journal of Cleaner Production, vol. 139, pp. 13621369, 2016, doi: 10.1016/j.jclepro.2016.08.075.

[32] I. Tapio, T. J. Snelling, F. Strozzi, and R. J. Wallace, "The ruminal microbiome associated with methane emissions from ruminan livestock," Journal of Animal Science and Biotechnology, vol. 8, no. 1, pp. 1-11, 2017, doi: 10.1186/s40104-017-0141-0.

[33] P. Mor et al., "Effect of ammonia fiber expansion on the available energy content of wheat straw fed to lactating cattle and buffalo in India," Journal of Dairy Science, vol. 101, no. 9, pp. 7990-8003, 2018 , doi: $10.3168 /$ jds.2018-14584.

[34] M. Mitsumori and W. Sun, "Control of rumen microbial fermentation for mitigating methane emissions from the rumen," Asian-
Australasian Journal of Animal Sciences, vol. 21, no. 1, pp. 144-154, 2008, doi: 10.5713/ajas.2008.r01.

[35] F. X. Philippe and B. Nicks, "Review on greenhouse gas emissions from pig houses: Production of carbon dioxide, methane and nitrous oxide by animals and manure," Agriculture, Ecosystems and Environment, vol. 199, pp. 10-25, 2015, doi: 10.1016/j.agee.2014.08.015.

[36] C. Martin, D. P. Morgavi, and M. Doreau, "Methane mitigation in ruminants: From microbe to the farm scale," Animal, vol. 4, no. 3, pp. 351-365, 2010, doi: 10.1017/S1751731109990620.

[37] Y. Widiawati, M. Winugroho, E. Teleni, and A. Thalib, "Fermentation kinetics (In-Vitro) of Leucaena leucocephala, Gliricidia sepium and Calliandra callothyrsus leaves (3) the pattern of gas production, organic matter degradation, $\mathrm{pH}, \mathrm{NH}_{3}$ and VFA concentration; estimated $\mathrm{CH} 4$ and microbial biomass production," Indonesian Journal of Animal and Veterinary Sciences, vol. 12, no. 3, pp. 202211, 2007. 